\title{
Effect of piglet castration with nonsurgical sterilant on the zootechnical performance and pork carcass quality
}

\author{
[Efeito da castração de leitões com esterilizante não cirúrgico no desempenho zootécnico e \\ na qualidade da carcaça suína] \\ D.S. Lucas $^{1}$, E.T.F. Siqueira ${ }^{2}$ (In Memoriam), M.M.H. Haguiwara ${ }^{2}$, S.S. Azevedo ${ }^{3}$, \\ S.E. Yotsuyanagi ${ }^{2}$, T.J.P. Silva ${ }^{1}$, F.R.M. Soto ${ }^{4 *}$ \\ ${ }^{1}$ Universidade Federal Fluminense - Niterói, SP \\ ${ }^{2}$ Instituto de Tecnologia de Alimentos - Campinas, SP \\ ${ }^{3}$ Universidade Federal de Campina Grande - Campina Grande, PB \\ ${ }^{4}$ Instituto Federal de Educação, Ciência e Tecnologia de São Paulo - Câmpus São Roque, SP
}

\begin{abstract}
A non-surgical sterilant (NSS) was used with the objective of assessing the zootechnical performance, carcass and meat quality, and hormone levels. 90 male piglets were selected with birthweights varying between $1.5 \mathrm{~kg}$ to $2.0 \mathrm{~kg}$. The control group was constituted of 45 males castrated by the conventional surgical method, at the seventh day of age, and the treated group was constituted of 45 males castrated with NSS (active principle of zinc gluconate in the concentration of $26.2 \mathrm{mg} / \mathrm{mL}$ associated to the dimethyl sulfoxide at $0.5 \%$ ), with the application of the first dose on the seventh day of age and the second dose on the fourteenth day of age. The zootechnical assessments were carried out on the farm and consisted: weight gain in the periods per animal and feed conversion. The slaughter of the animals and the assessment of the carcass and meat quality and hormone levels were carried out in a slaughterhouse and the municipality of Campinas (SP). The study demonstrated that the use of NSS was a viable alternative in relation to the zootechnical performance and the carcass quality. In relation to the meat quality there was no significant difference in the majority of the assessed parameters.
\end{abstract}

Keywords: swine, zinc gluconate, androstenone, feed conversion, carcass yield

\section{RESUMO}

Foi utilizado esterilizante não cirúrgico (ENC) com o objetivo de se avaliar o desempenho zootécnico e a qualidade de carcaça, de carne e de níveis hormonais. Foram selecionados 90 leitões machos de peso entre $1,5 \mathrm{~kg}$ e $2,0 \mathrm{~kg}$ ao nascimento. O grupo controle foi constituído por 45 machos castrados pelo método cirúrgico convencional, ao sétimo dia de idade, e o grupo tratado foi constituído por 45 machos castrados com ENC (princípio ativo de gluconato de zinco na concentração de 26,2 $\mathrm{mg} / \mathrm{mL}$ associado ao dimetil sulfóxido a 0,5\%), com primeira dose de aplicação ao sétimo dia de idade e a segunda dose ao $14^{\circ}$ dia de idade. As avaliações consistiram de: ganho de peso nos períodos por animal e conversão alimentar. $O$ abate dos animais e a avaliação da carne e de níveis hormonais foram realizados em um frigorífico, na cidade de Campinas (SP). O uso de ENC foi uma alternativa viável em relação ao desempenho zootécnico e à qualidade da carcaça. Em relação à qualidade da carne, não houve diferença significativa na maioria dos parâmetros avaliados.

Palavras-chave: suínos, gluconato de zinco, androstenona, conversão alimentar, rendimento de carcaça

\section{INTRODUCTION}

The search for technologies which enable the production of animals with a better zootechnical performance, carcasses with a higher yield and

Recebido em 7 de maio de 2016

Aceito em 30 de maio de 2016

*Autor para correspondência (corresponding author)

E-mail: chicosoto34@gmail.com / sotofrm@ifsp.edu.br lean meat quality is a constant challenge of the technified swine-farming (Martins et al., 2013). Such advances must be in harmony with the aspects associated to animal well-being and the sustainability of the pork meat production activity (Tuyttens et al., 2012). 
The consumer's change of attitude regarding a higher demand for lean meat combined with lower production costs associated to uncastrated males lead to the elimination of castration in cattle and sheep farming (Andreo et al., 2013). However, this procedure in the swine species is still recurrent is some countries, such as Brazil, due to the androsterone, a steroid produced in the animal's testicles during sexual maturity, which exhales an unpleasant smell during the cooking of the meat which causes rejection of the meat by the consumers (Iocca et al., 2015). In this context, studies are necessary for the development of viable alternatives to the conventional surgical castration of male piglets, still practiced in the majority of swine farms in Brazil and, largely, without the use of anesthetic drugs (Leclercq et al., 2014).

Non-surgical approaches to eliminate the testicular functionality have been developed in companion and production animals, based on the intratesticular application of a variety of reagents which induce fibrosis, orchitis, and tissue destruction. One of these attempts involves the intratesticular application of solutions containing neutralized zinc gluconate (Vannucchi et al., 2015), which is regarded as being a non-surgical sterilant (NSS) of a low cost and easy application (Cavalieri et al., 2015).

Therefore, this work aimed to assess the effect of the intratesticular application of the NSS, in piglets in the lactating stage, in relation to the zootechnical performance, carcass and meat quality, and skatole and androtestone hormone levels.

\section{MATERIAL AND METHODS}

The rearing of the animals took place at a fullcycle commercial swine farm in the municipality of Capivari, SP, Brazil. The slaughter was carried out in a slaughterhouse located in the municipality of Amparo, SP, Brazil, and the analysis were performed at the Food Technology Institute (FTI) located in Campinas, SP, Brazil.

The experiment was approved by the Bioethics committee of the State University of Campinas under protocol number 0028.0.147.000-10.

At the farm, the animals were housed in stalls containing semi-automatic feeders, and nipple type drinkers, with an area of $0.40 \mathrm{~m}^{2} /$ animal at the nursery stage and $1.00 \mathrm{~m}^{2} /$ animal termination stage. The stalls, with concrete floors, in masonry barns covered with clay tiles, totalizing $250 \mathrm{~m}^{2}$ in the nursery and $1.800 \mathrm{~m}^{2}$ in the termination.

The swine were prevenient from Agroceres Genetic Company PIC ${ }$, and their parents, the males from the AGIPIC $® 337$ lineage and AGIPIC ${ }^{\circledR} 415$ of superior/elite lineage, and and their mothers from the Camborough $25 \AA$ lineage.

90 males with birthweights between $1.5 \mathrm{~kg}$ to $2.0 \mathrm{~kg}$ were selected. The control group was constituted of 45 males castrated by the conventional surgical method, on the seventh day of age, and the treated group was constituted of 45 males castrated by the NSS (active principle of zinc gluconate at the concentration of $26.2 \mathrm{mg} / \mathrm{mL}$ associated to the dimethyl sulfoxide), with the first dose application on the seventh day of age and the second dose on the $14^{\text {th }}$ day of age. After the castration of the control and treated group, all the animals were identified by Australian type marking, and returned to the matrices to proceed with the lactation stage.

The NSS was applied at the volume of $0.5 \mathrm{ml}$ per testicle, by intratesticular injection, using insulin needles $(0.3 \mathrm{~mm} \times 13 \mathrm{~mm})$, always starting on the left side. The piglets were placed in dorsal ventral position, and the needle was inserted in the dorsal cranial portion of the testicle and below the epididymis. The procedure was carried out under aseptic conditions, respecting the animal welfare laws.

The animals in the nursery and growth stage (1 to 49 days of life) received a commercial diet made of ground maze, soybean meal and mineral vitamin supplement with values of 3.180 to $3.400 \mathrm{kcal}$ and $14 \%$ to $23 \%$ crude protein, depending on the age and the animals' nutritional requirements.

The zootechnical assessments were carried out at the farm at weaning and termination stage and consisted of the zootechnical performance, being these: weight gain during the periods (WGP) per animal and feed conversion (FC) per stall. These parameters were assessed from 21 days of age and following the schedule of the housing days: $35,49,70,98,105,126$, and 161 days. 
The principles of humane slaughtering were respected in the pre-slaughter and slaughter handling stages. When they reached 162 days of age they were transported to the slaughterhouse $250 \mathrm{~km}$ away. The swine were housed in collective stalls with unrestricted access to drinking water, respecting the solid fast period of 12 hours in the commercial farm and of six hours in the slaughterhouse. The animals were desensitized by electronarcosis ( 350 to $450 \mathrm{v}$ and 1.2 A). The assessment of the skin lesions was performed, according to the methodology described by Barton Gade et al. (1996).

The carcass quality was assessed by means of on line classification, by the insertion of an optical reader (Hennessy(C) Grading System GP4/BP4, DIDAI, United States) perpendicular to the midline of the carcass at the height of the last rib, with six to eight $\mathrm{cm}$ distance from the referred line.

The carcass length was also measured in centimeters from the cranial border of the pubic symphysis to the cranial border of the first rib (Meat, 2001).

The measurement of fat thickness was performed using a digital pachymeter (Electronic Digital Caliper) on the fat of each half carcass on the following positions: height of the first (TT1) thoracic vertebrae, last lumbar vertebrae (TT3) and the maximum fat thickness along the dorsum (TT1, TT3 and maximum fat thickness) (Meat, 2001).

The length of the loin eye muscular region was measured at the height between the $10^{\text {th }}$

and the $11^{\text {th }}$ rib. At this height the fat depth (FD10a) was also measured. The loin eye area (LEA) was measured using a plastic matrix (Grid) formed by squares with a height of $1.0 \mathrm{~cm}^{2}$ each, thus obtaining the total area from the counting of the squares which were found on the surface of the LEA (Meat, 2001).

At the end of the slaughter line, the carcasses were weighed and divided longitudinally.

For the calculation of the carcass composition, 30 left half carcasses from each treatment were boned in anatomical cuts and dissected according to the method described by Walstra and Merkus (1996). The skin lesion scores were obtained visually in the shank, palette, and body of the carcasses, based on a standard guide of photographs $(0=$ absence, $1=$ light, $2=$ moderate, $3=$ severe).

The $\mathrm{pH}$ (Model H199163, Hanna, USA) was measured after 45 minutes and 24 hours postmortem under refrigeration at $2 \pm 1^{\circ} \mathrm{C}$. The measures were collected in duplicate, in the Longissimus dorsi muscle (at the height of the last rib) and in the semimembranosus.

For the analysis of weight loss due to cooking, a sample of $30 \mathrm{~cm}$ of the Longissimus dorsi muscle was sectioned from a cooled carcass, from the area between the last thoracic vertebrae and the first lumbar. The muscle was sectioned, through transversal cuts, removing samples of approximately $2.5 \mathrm{~cm}$ thick. These samples were weighed (initial weight) and thermally treated on a hot plate (George Foreman Grill, United States), at a temperature of $180^{\circ} \mathrm{C}$. The samples were turned over when these reached an internal temperature of $42^{\circ} \mathrm{C}$, measured with a thermometer (Testo, model 106, Brazil) and removed from the hot plate when they reached the internal temperature of $72^{\circ} \mathrm{C}$. The samples were weighed (final weight) when reaching the external temperature of $40^{\circ} \mathrm{C}$. The difference between the initial weight and the final weight corresponded to the weight loss due to cooking, being expressed in percentage (\%).

For the assessments of loss by exudation and water retention capacity (WRC), samples with $20 \mathrm{~cm}$ of diameter of the Longissimus dorsi and Semimembranosus muscles were used in replicate, respectively, 24 hours post-mortem. The assessment of loss by exudation was based on the Danish method, a methodology adopted and developed according to the Danish Meat Research Institute (DMRI- Danish Meat Research Institute) cited by Correa et al. (2007). The water retention capacity was executed according to the methodology described and modified by Houfmann et al. (1982).

For the analysis of the shearing force, three samples originated from the analysis of weight loss due to cooking were used, maintained refrigerated overnight at $4^{\circ} \mathrm{C}$. From each sample five pieces were taken with the aid of a cylindrical sampler of $15 \mathrm{~mm}$ diameter. A texturemeter was used, previously calibrated, of the TA XT-2i model and Stable Micro System brand (England) with a Warner Braztler probe ( $3 \mathrm{~mm}$ thickness). The test speed was of $2 \mathrm{~mm} / \mathrm{s}$. 
For the determination of the concentration of skatole and androstenone, the samples of back fat were collected in the slaughter period and analyzed for the quantification of the compounds of sexual odor. The analysis was performed based on the technique described by Dehnhard et al. (1993) and Hansen-Moller (1994). The determination of these compounds was carried out by means of High Performance Liquid Chromatograph with Fluorescence Detector.

Samples of 200 grams of liver were collected after the inspection of the viscera for the determination of the zinc levels according to the methodology preconized by Official (2005).
The results were analyzed using the Stastistical (2009), and the animal was considered as being the experimental unit, and the differences between the means were analyzed by Tukey's test. The difference between the treatments $(\mathrm{P} \leq 0.05)$ and tendencies $(\mathrm{P} \leq 0.1)$ were analyzed (Zar, 1999).

\section{RESULTS AND DISCUSSION}

The results of the animals' zootechnical performance regarding weight gain and average weight in the housing periods corresponding to each stage are presented in Table 1.

Table 1. Weight gain and average weight of the animals per type of feed (growth period) in the control and castrated with non-surgical sterilant (NSS) groups

\begin{tabular}{ccccc}
\hline & \multicolumn{2}{c}{ Average weight } & \multicolumn{2}{c}{ Weight gain } \\
\hline $\begin{array}{c}\text { Type of feed } \\
\text { (period in days) }\end{array}$ & Control & NSS & Control & NSS \\
\hline Precocious (0 - 21) & $1.6 \pm 0.0^{\mathrm{a}}$ & $1.6 \pm 0.0^{\mathrm{a}}$ & $4.3 \pm 0.1^{\mathrm{a}}$ & $4.4 \pm 0.1^{\mathrm{a}}$ \\
Pre Initial I (22-35) & $5.9 \pm 0.1^{\mathrm{a}}$ & $6.1 \pm 0.1^{\mathrm{a}}$ & $3.2 \pm 0.1^{\mathrm{a}}$ & $3.0 \pm 0.1^{\mathrm{a}}$ \\
Pre Initial II (36-49) & $9.1 \pm 0.2^{\mathrm{a}}$ & $9.1 \pm 0.2^{\mathrm{a}}$ & $7.4 \pm 0.1^{\mathrm{b}}$ & $8.1 \pm 0.2^{\mathrm{a}}$ \\
Initial (40-63) & $16.5 \pm 0.3^{\mathrm{a}}$ & $17.3 \pm 0.4^{\mathrm{a}}$ & $12.0 \pm 0.3^{\mathrm{a}}$ & $12.1 \pm 0.3^{\mathrm{a}}$ \\
Initial II (64-77) & $28.5 \pm 0.5^{\mathrm{a}}$ & $29.4 \pm 0.6^{\mathrm{a}}$ & $13.9 \pm 0.4^{\mathrm{a}}$ & $13.5 \pm 0.4^{\mathrm{a}}$ \\
Initial III (78-98) & $42.4 \pm 0.7^{\mathrm{a}}$ & $43.0 \pm 0.8^{\mathrm{a}}$ & $21.2 \pm 0.6^{\mathrm{a}}$ & $21.0 \pm 0.4^{\mathrm{a}}$ \\
Growth I (99-112) & $63.6 \pm 0.9^{\mathrm{a}}$ & $64.1 \pm 1.0^{\mathrm{a}}$ & $15.4 \pm 0.6^{\mathrm{a}}$ & $16.9 \pm 0.5^{\mathrm{a}}$ \\
Growth II (113-133) & $79.1 \pm 1.0^{\mathrm{a}}$ & $81.0 \pm 1.2^{\mathrm{a}}$ & $23.8 \pm 1.4^{\mathrm{a}}$ & $25.2 \pm 0.7^{\mathrm{a}}$ \\
Fattening I (134-148) & $102.9 \pm 1.2^{\mathrm{a}}$ & $106.2 \pm 1.5^{\mathrm{a}}$ & $20.4 \pm 0.9^{\mathrm{a}}$ & $19.6 \pm 0.7^{\mathrm{a}}$ \\
Final Fattening (149-162) & $121.0 \pm 1.7^{\mathrm{a}}$ & $125.9 \pm 1.8^{\mathrm{a}}$ & $16.9 \pm 0.8^{\mathrm{a}}$ & $12.8 \pm 0.7^{\mathrm{b}}$ \\
Fast (176 - slaughter) & $138.0 \pm 2.0^{\mathrm{a}}$ & $138.7 \pm 2.0^{\mathrm{a}}$ & $-2.0 \pm 0.4^{\mathrm{a}}$ & $-1.0 \pm 0.3^{\mathrm{a}}$ \\
Slaughter & $135.9 \pm 2.2^{\mathrm{a}}$ & $137.6 \pm 2.0^{\mathrm{a}}$ & - & - \\
\hline
\end{tabular}

NSS: Non-surgical sterilant; Mean \pm standard error, $n=44$; Lower case letters differ significantly $(\mathrm{P}<0.05)$ between the treatments.

In the results presented in Tab.1, it can be observed that there was no relevant difference between the treatments. However for weight gain in the same period only in two stages (36-49 and 148-162 days of age) the differences were significant between the treatments, demonstrating that the present investigation requires more studies in the field, since the lower consumption of feed reflects a positive profitability of the swine production system.

It was observed that the treatment group presented better results for weight gain still in the Pre-Initial II stage. However, in the fattening stage, the NSS group presented a lower weight gain and a lower feed efficiency in comparison with the control group. It appears that this difference in the fattening stage may be related to the differentiated nutritional demand between the two treatments, as it is possible that the nonsurgically sterilized male swine may not present a higher demand for amino acids in their diets, a similar behavior to uncastrated. These, in turn, present a higher demand for amino acids in relation to the males castrated by the conventional method (Dunshea et al., 1993). Therefore, it is possible that the concentration of amino acids in the diet offered to both treatments have been insufficient to attend the growth biological demand of the NSS group when fed with the same diet as the control group.

In Table 2 the feed conversion results of the animals in the control and castrated with nonsurgical sterilant groups are presented. 
Effect of piglet...

Table 2. Feed conversion of the animals per feed type, growth period in the control and castrated with non-surgical sterilant (NSS) groups

\begin{tabular}{ccccc}
\hline Type of feed & Growth period & Control & NSS & $P$ value \\
\hline Precocious & 0-21days & $0.3 \pm 0.0^{\mathrm{a}}$ & $0.35 \pm 0.0^{\mathrm{a}}$ & 0.3995 \\
Pre initial I & 22-35days & $0.5 \pm 0.0^{\mathrm{b}}$ & $0.70 \pm 0.0^{\mathrm{a}}$ & 0.0030 \\
Pre initial II & 36-49days & $1.1 \pm 0.0^{\mathrm{a}}$ & $1.03 \pm 0.0^{\mathrm{a}}$ & 0.0563 \\
Initial & 50-63days & $0.4 \pm 0.0^{\mathrm{a}}$ & $0.32 \pm 0.0^{\mathrm{b}}$ & $<0.0001$ \\
Initial II & 64-77days & $1.0 \pm 0.0^{\mathrm{a}}$ & $1.12 \pm 0.0^{\mathrm{a}}$ & 0.0936 \\
Initial III & 78-98days & $1.6 \pm 0.1^{\mathrm{a}}$ & $1.52 \pm 0.0^{\mathrm{a}}$ & 0.5345 \\
Growth I & 99-112days & $3.7 \pm 0.1^{\mathrm{a}}$ & $2.72 \pm 0.1^{\mathrm{b}}$ & $<0.0001$ \\
Growth II & $113-13$ days & $2.1 \pm 0.1^{\mathrm{a}}$ & $1.67 \pm 0.1^{\mathrm{b}}$ & 0,0500 \\
Fattening I & $134-148$ days & $3.9 \pm 0.4^{\mathrm{a}}$ & $3.58 \pm 0.2^{\mathrm{a}}$ & 0.4521 \\
Final fattening & $148-162$ days & $6.0 \pm 0.3^{\mathrm{b}}$ & $7.31 \pm 0.3^{\mathrm{a}}$ & 0.0060 \\
\hline
\end{tabular}

Mean \pm standard error, $n=44$; Lower case letters differ significantly $(P<0.05)$ between the treatments.

Pauly et al. (2008) reported that surgically castrated male swine presented a higher consumption in relation to the uncastrated males, whose response may be related to the low concentration of testosterone in these animals (Dunshea et al., 2001), which will probably result in a worsening in feed conversion. In the present work, a significant difference in the initial, growth, and fattening stages in the feed consumption was detected (Table 2). These results were considerable, as the difference in consumption was of less $10 \mathrm{~kg}$ of feed by the group NSS treated or still $0.83 \mathrm{~kg}$ more feed consumed daily by the control group. This way, in this parameter, an economical advantage of the NSS group can be observed, as it consumed less feed than the control group and the weight gain in this period was equal between the treatments (Table 1).

Among the assessed performance data the feed conversion parameter is highlighted. In Tab. 2, overall, it can be determined that, analyzing all the stages, the swine of the NSS group had a better feed conversion than those of the control group, as for the ten stages, the NSS presented lower conversion $(P<0.05)$ in three stages in addition to presenting lower conversion $(P>$ 0.05 ) in four more stages, whilst the control group presented significant lower feed conversion $(P<0.05)$ in only two stages and in one stage $(P>0.05)$. The lower feed conversion showed once again it's advantage from the economic point of view, regardless of the small difference presented by the animals of the NSS group, which demonstrated a better feed efficiency during a longer period of the productive life in comparison with the animals in the control group.

Table 3 and 4 present the results of the carcass quality measures and dissections in the control and NSS groups.

Table 3. Carcass quality measures in the control and castrated with non-surgical sterilant (NSS) groups

\begin{tabular}{ccc}
\hline Carcass measures & Control & NSS \\
\hline Carcass lenght & $83.9 \pm 0.5^{\mathrm{b}}$ & $85.6 \pm 0.5^{\mathrm{a}}$ \\
TT1 & $36.3 \pm 0.8^{\mathrm{a}}$ & $31.9 \pm 0.8^{\mathrm{b}}$ \\
TT3 & $21.9 \pm 1.4^{\mathrm{a}}$ & $15.4 \pm 0.6^{\mathrm{b}}$ \\
Maximum thickness of lumbar fat & $32.3 \pm 0.6^{\mathrm{a}}$ & $30.4 \pm 1.2^{\mathrm{a}}$ \\
FD10a & $22.0 \pm 0.9^{\mathrm{a}}$ & $16.4 \pm 1.0^{\mathrm{b}}$ \\
Loin eye area & $57.7 \pm 1.2^{\mathrm{a}}$ & $56.3 \pm 1.1^{\mathrm{a}}$ \\
Loin length & $94.9 \pm 1.2^{\mathrm{b}}$ & $101.8 \pm 0.9^{\mathrm{a}}$ \\
Weight of half cold carcass & $54.3 \pm 0.8^{\mathrm{a}}$ & $53.4 \pm 0.8^{\mathrm{a}}$ \\
Weight of hot carcass (kg) & $116.05 \pm 1.6^{\mathrm{a}}$ & $113.9 \pm 1.6^{\mathrm{a}}$ \\
Fat (mm) Electronic typification & $18.6 \pm 0.5^{\mathrm{a}}$ & $16.3 \pm 0.5^{\mathrm{b}}$ \\
Musculature (mm) Electronic typification & $65.2 \pm 1.2^{\mathrm{a}}$ & $70.0 \pm 1.2^{\mathrm{a}}$ \\
\hline
\end{tabular}

Mean \pm stardand error, $\mathrm{n}=44$

Letters differ significantly $(P<0.05)$ between the treatments. 
Table 4. Dissection in the control and castrated with non-surgical sterilant (NSS)

\begin{tabular}{|c|c|c|c|}
\hline Dissection & & NSS & Control \\
\hline \multirow{3}{*}{ Shank } & Meat & $9.7 \pm 0.2^{\mathrm{a}}$ & $8.9 \pm 0.2^{b}$ \\
\hline & Total fat & $1.3 \pm 0.1^{\mathrm{b}}$ & $2.0 \pm 0.1^{\mathrm{a}}$ \\
\hline & Total & $12.6 \pm 0.3^{\mathrm{a}}$ & $12.6 \pm 0.2^{\mathrm{a}}$ \\
\hline \multirow{3}{*}{ Rack } & Meat & $5.0 \pm 0.2^{\mathrm{a}}$ & $4.8 \pm 0.2^{\mathrm{a}}$ \\
\hline & Subcutaneous fat & $1.6 \pm 0.1^{\mathrm{b}}$ & $2.2 \pm 0.1^{\mathrm{a}}$ \\
\hline & Total & $8.9 \pm 0.3^{\mathrm{a}}$ & $9.2 \pm 0.3^{\mathrm{a}}$ \\
\hline Fillet & Total & $0.8 \pm 0.0^{\mathrm{a}}$ & $0.7 \pm 0.0^{b}$ \\
\hline \multirow{3}{*}{ Stomach } & Meat & $3.4 \pm 0.1^{\mathrm{a}}$ & $3.4 \pm 0.1^{\mathrm{a}}$ \\
\hline & Subcutaneous fat & $0.9 \pm 0.1^{\mathrm{b}}$ & $1.1 \pm 0.1^{\mathrm{a}}$ \\
\hline & Total & $5.3 \pm 0.2^{\mathrm{a}}$ & $5.5 \pm 0.2^{\mathrm{a}}$ \\
\hline \multirow{3}{*}{ Ventral stomach } & Meat & $0.4 \pm 0.0^{\mathrm{a}}$ & $0.3 \pm 0.0^{b}$ \\
\hline & Subcutaneous fat & $0.3 \pm 0.0^{b}$ & $0.4 \pm 0.0^{\mathrm{a}}$ \\
\hline & Total & $0.8 \pm 0.0^{\mathrm{a}}$ & $0.8 \pm 0.0^{\mathrm{a}}$ \\
\hline \multirow{3}{*}{ Flank steak } & Meat & $1.0 \pm 0.1^{\mathrm{a}}$ & $1.0 \pm 0.0^{\mathrm{a}}$ \\
\hline & Subcutaneous fat & $0.5 \pm 0.0^{\mathrm{b}}$ & $0.8 \pm 0,1^{\mathrm{a}}$ \\
\hline & Total & $1.7 \pm 0.1^{\mathrm{a}}$ & $2.0 \pm 0.1^{\mathrm{a}}$ \\
\hline \multirow{3}{*}{ Breast boné } & Meat & $1.1 \pm 0.0^{\mathrm{a}}$ & $1.1 \pm 0.1^{\mathrm{a}}$ \\
\hline & Internal fat & $0.2 \pm 0.1^{\mathrm{b}}$ & $0.3 \pm 0.0^{\mathrm{a}}$ \\
\hline & Total & $2.0 \pm 0.0^{\mathrm{a}}$ & $2.0 \pm 0.1^{\mathrm{a}}$ \\
\hline \multirow{3}{*}{ Pallete } & Meat & $4.7 \pm 0.1^{\mathrm{a}}$ & $4.3 \pm 0.1^{b}$ \\
\hline & Total fat & $1.0 \pm 0.1^{\mathrm{b}}$ & $1.2 \pm 0.0^{\mathrm{a}}$ \\
\hline & Total & $6.9 \pm 0.1^{\mathrm{a}}$ & $6.6 \pm 0.1^{\mathrm{a}}$ \\
\hline \multirow{3}{*}{ Boston butt } & Meat & $2.7 \pm 0.2^{\mathrm{a}}$ & $2.6 \pm 0.1^{\mathrm{a}}$ \\
\hline & Total fat & $0.6 \pm 0.0^{b}$ & $0.7 \pm 0.0^{\mathrm{a}}$ \\
\hline & Total & $4.1 \pm 0.1^{\mathrm{a}}$ & $4.0 \pm 0.1^{\mathrm{a}}$ \\
\hline \multirow{3}{*}{ Forearm } & Meat & $0.5 \pm 0.0^{\mathrm{a}}$ & $0.4 \pm 0.0^{b}$ \\
\hline & Subcutaneous fat & $0.1 \pm 0.0^{\mathrm{a}}$ & $0.1 \pm 0.0^{\mathrm{a}}$ \\
\hline & Total & $1.1 \pm 0.0^{\mathrm{a}}$ & $1.0 \pm 0.0^{\mathrm{b}}$ \\
\hline \multirow{3}{*}{ Leg } & Meat & $1.0 \pm 0.0^{\mathrm{a}}$ & $0.8 \pm 0.0^{b}$ \\
\hline & Subcutaneous fat & $0.1 \pm 0.0^{\mathrm{a}}$ & $0.2 \pm 0.0^{\mathrm{a}}$ \\
\hline & Total & $1.7 \pm 0.0^{\mathrm{a}}$ & $1.5 \pm 0.0^{\mathrm{b}}$ \\
\hline Jowl & Total & $1.7 \pm 0.1^{\mathrm{a}}$ & $1.8 \pm 0.1^{\mathrm{a}}$ \\
\hline
\end{tabular}

Mean \pm standard error of the weight of each cut and their dissected portions, $\mathrm{n}=30$

Lower case letters differ significantly $(\mathrm{P}<0.05)$ between the treatments.

For the carcass quality parameter, (Tab.3), even though a difference regarding weight between the treatments was not noticed, significant differences related to other items were detected between the groups. According to the measures of electronic typification of the carcasses of the NSS group, these presented a smaller fat thickness $(\mathrm{P}<0.05)$ and a tendency $(P=0.11)$ to a greater depth of lean meat in the carcass. It is known that the back fat thickness presents a (inverse) correlation with the quantity of lean meat (Dutra et al., 2001). This information was corroborated by the data found in the linear measurements made in this experiment. The data obtained in this research confirmed those found by Latorre et al. (2008), which indicated a high correlation between the deposition of protein in the carcass, weight gain and feed conversion.

Still in the present study, by means of the assessment of the linear measurements, it was possible to verify that the carcasses of the animals in the control group presented a greater fat thickness in the TT 1 and TT 3 measurements, corroborating with the assessment of the electronic pistol. It can also be noticed a greater length $(P<0.05)$ of the carcasses of the NSS group, as well as a greater length of the loin (LL) $(\mathrm{P}<0.05)$, in addition the fat depth at the height of the 10th thoracic vertebrae, which was lower in the NSS group compared to the control group. The results of the present experiment are similar 
to some of the results founds by MartinezMacipe et al. (2016) when comparing the carcasses of the surgically castrated and immunocastrated animals. The animals from the NSS group are similar to the immunocastrated ones, presenting carcasses with smaller fat thickness, greater carcass length and better meat yield for some of the meat cuts (Tab. 3 and 4). These assessed differences indicated a better carcass quality, with a greater quantity of lean meat from the animals from the NSS group in relation to the control group.

The male swine from the NSS group presented a better $(P<0.05)$ meat yield for the prominent meat cuts such as the shank, ventral stomach and pallete, and also the fillet, forearm and leg cuts $(P<0.05)$, when compared to the control group (Tab. 4). It can be noticed that, with the exception of the forearm and leg cuts, in all the other assessed cuts, the quantity of fat of the NSS group was smaller $(P<0.05)$ in comparison to the control group. Based on this information, it is highlighted that the animals of the NSS group presented meat cuts with a smaller quantity of fat and consequently a higher meat yield.

Tab. 5 are presents the results in relation to meat quality in the control and NSS groups.

Table 5. Meat quality in the control and castrated with non-surgical sterilant (NSS) groups

\begin{tabular}{ccc}
\hline Quality of the meat & Control & NSS \\
\hline Colour (subjective) & $2.5 \pm 0.1^{\mathrm{a}}$ & $2.3 \pm 0.1^{\mathrm{a}}$ \\
Marbling (subjective) & $1.1 \pm 0.0^{\mathrm{a}}$ & $1.0 \pm 0.0 \mathrm{~b}$ \\
Pre-rigor & $2.1 \pm 0.1 \mathrm{a}$ & $2.4 \pm 0.1^{\mathrm{a}}$ \\
$\mathrm{pH}$ topside pad 45 minutes & $6.4 \pm 0.0^{\mathrm{a}}$ & $6.6^{\mathrm{a}} \pm 0.0^{\mathrm{a}}$ \\
$\mathrm{pH}$ loin 24 hours & $5.8 \pm 0.0^{\mathrm{a}}$ & $5.8^{\mathrm{a}} \pm 0.0^{\mathrm{a}}$ \\
$\mathrm{pH}$ topside pad 24 hours & $5.8 \pm 0.0^{\mathrm{a}}$ & $5.8 \pm 0.0^{\mathrm{a}}$ \\
Water retention capacity & $0.3 \pm 0.0 \mathrm{a}$ & $0.2 \pm 0.0^{\mathrm{b}}$ \\
Loss by exudation (\%) & $2.2 \pm 0.2 \mathrm{a}$ & $2.4 \pm 1.2 \mathrm{a}$ \\
Loss by cooking (\%) & $24.2 \pm 0.8 \mathrm{a}$ & $25.2 \pm 0.8 \mathrm{a}$ \\
Shearing force & $4.6 \pm 0.2 \mathrm{a}$ & $4.4 \pm 0.2 \mathrm{a}$ \\
\hline
\end{tabular}

Mean \pm standard error, $\mathrm{n}=44$

Lower case letters differ significantly $(P<0.05)$ between the treatments.

It was observed that in both treatments the prerigor assessment did not generate average values below or equal to $110^{\circ}$, as well as according to the $\mathrm{pH}$ values. There was no incidence of PSE (Pale, Soft and Exudative) meat in any of the assessed treatments. This way the $\mathrm{pH}$ values, both at 45 minutes and 24 hours after the slaughter were within acceptable values, and there was no difference between the treatments. With the exception of water retention capacity and subjective marbling index in which the NSS group presented slightly lower values, the other results did not present any significant differences in relation to the meat quality.

Comparing the results of WRC obtained during accomplishment of the present experiment, it was observed that in both treatments the obtained WRC values were low. This reduction may have occurred due to the large manipulation that the meat samples suffered during the stages prior to the determination of the WRC, as well as the $\mathrm{pH}$ measurements and losses by exudation.
However, all the procedures for the WRC determination were identical in both the assessed experimental stages, not privileging any of the studied treatments. In the weight loss assessments by cooking and by exudation (Tab. 5) significant differences were not observed for these parameters, which indicates that the meat quality in this aspect is similar among the treatments.

Still in this sense it is known that high values of drip loss and cooking loss, as well as low WRC values may be related to the high slaughter weight of the animals, a factor that is correlated to the assessed parameters. Weatherup et al. (1998) reported an increase in the cooking loss due to the increase of the weight at slaughter.

In relation to the average values of the meat's shear force (Tab. 5), difference between the groups was not observed. However, they presented high values $(P<0.05)$ of shear force for both treatments. The average shear force 
values determined in this work were higher than $3.2 \mathrm{kgf}$, a value considered as being the limit between the tenderness and hardness in swine meat. Iversen et al. (1995) proposed 6.0kgf as being the limit between tender and hard meat for swine.

The average values of skin lesion scores in the region of the shank, body, and pallete demonstrated that the incidences were low, from absent to light, not differing $(P>0.05)$ for the two groups.

It was noticed that in the NSS group there was no difference in relation to the classifications of skin lesions, and it can be inferred that these animals did not present a more aggressive behavior in relation to the control group, and did not present an incidence of severe lesion in the carcass, as scores 3 and 4 were not noted. Dalmau et al. (2009) assessed the pre-slaughter handling in 10 slaughterhouses and noted that the majority of the assessed animals were classified as score 1, confirming with the values found in this experiment. Bünger et al. (2015) when comparing females, castrated males and uncastrated males noticed that the uncastrated animals presented a higher incidence of skin lesions in the score 1 and 2. In the present study, the animals of the NSS group could be similar to the uncastrated animals as they remained with their testicles for lifetime or still for having the testicular function active for more time than the animals of the control group. Nevertheless, this did not affect the incidence of skin lesions in the animals. As for the number of lesions we can notice that the lesion rates in the animals of the NSS group was smaller than the rate of the control group.

The zinc concentration found in the liver of the swine of the NSS group, was within the normal parameters according to Bertol and Brito (1998) and is of 10 to $30 \mathrm{mg} / 100 \mathrm{~g}$, not bringing toxicity to the animals. Also, a significant difference between the NSS and control group was not noticed, and it may be inferred that the dose of the sterilant did not generate an increase in the zinc concentrations in the livers of the animals of the NSS group.

As for the results of the analysis of the concentrations of skatole and androtestone in the 37 samples of the NSS group, it can be noticed that in the majority, the values detected were considered as being low, and the average of this compound did not differ from the average of the control group.

Although there are reports that the absence of skatole in the sample causes the assessment of sexual odor not to be well differentiated from the samples of animals without this odor (females) (Bonneau and Chevillon, 2012), it is worth highlighting that even in low concentrations of this compound, but with high concentrations of androstenone, the odor becomes more perceptible and, consequently, there will be a lower acceptance by consumers, due the perceptible presence of odor and male taste.

In relation to the concentration of androstenone in the samples of the NSS group, some samples with values considered as being high can be noticed (Bonneau, Chevillon, 2012), which demonstrated that the method was not effective in some animals (in 19 samples from the 37 assessed). This fact reinforces the need to carry out more assessments of this methodology and its protocols, so as to optimize its use and yield of success in the application of the product. Nevertheless, it can be noticed that in 17 samples the values of the concentration of androstenone stayed below $1 \mu \mathrm{g} / \mathrm{g}$, and can be considered as being acceptable.

It could also be verified that classifications are usually established regarding the androstenone content according to the range of values, and those samples which presented values below $0.5 \mu \mathrm{g} / \mathrm{g}$ were considered as low, those with concentrations below $1 \mu \mathrm{g} / \mathrm{g}$ as medium, those above $1 \mu \mathrm{g} / \mathrm{g}$ as high, and samples with concentrations above $2 \mu \mathrm{g} / \mathrm{g}$ were very high (Bonneau, Chevillon, 2012). The samples were classified this way and, despite no sensorial analysis having been carried out (important for the next assessments) it was aimed to infer the intensity of the sexual odor in the assessed samples according to their respective concentrations of the compounds skatole and androstenone.

These results demonstrated that in some animals, the assessed methodology was not effective in reducing the compounds responsible for the sexual odor, and probably also maintained these animals uncastrated. This may have influenced 
the zootechnical performance, quality of the carcass and yield of cuts, as it is known that uncastrated animals produce in their testicles natural anabolic agents, which collaborate in improving the zootechnical performance and with the greater deposition of lean tissue (Bonneau et al., 1992).

\section{CONCLUSIONS}

In this experiment, according to the results of zootechnical performance, it can be inferred that the process of non-surgical sterilization (with zinc gluconate and dimethyl sulphoxide) showed to be a viable alternative to the surgical castration of male swine, resulting in greater meat content and lower fat thickness. However, it is noticed that there was an incidence of animals which presented a high concentration of androstenone analyzed in the costal-lumbar fat, and this fact must be taken into consideration so that the application methodology may be reviewed and optimized. In this way more studies with the non-surgical sterilant are necessary.

\section{ACKNOWLEGEMENTS}

The authors are grateful for the supply of materials by the Rhobifarma and Agroceres PIC so that this work could be accomplished. The authors are also grateful to the CAPES for the financial support (PhD scholarship).

\section{REFERENCES}

ANDREO, N.; BRIDI, A.M.; TARSITANO, M.A. et al. Influência da imunocastração (Bopriva $\left.{ }^{\circledR}\right)$ no ganho de peso, características de carcaça e qualidade da carne de bovinos nelore. Semin. Cienc. Agrar., v.34, p.4121-4132, 2013.

BARTON GADE, P.P.D.; WARRISS, S.N.; BROWN, E. et al. Methods of improving pig welfare and meat quality by reducing stress and discomfort before slaughter - methods of assessing meat quality. NEW INFORMATION ON WELFARE AND MEAT QUALITY OF PIGS AS RELATED TO HANDLING, TRANSPORT MEAT QUALITY OF PIGS AS RELATED TO HANDLING, TRANSPORT. 1996, Mariensee. Seminar... Mariensee: EU, 1996. p.23-34.
BERTOL, T.M.; BRITO, B.G. Efeito de altos níveis de zinco suplementar no desempenho e na mortalidade de leitões. Pesqui. Agropecu. Bras., v.33, p.1493-1501, 1998.

BONNEAU, M.; CHEVILLON, P. Acceptability of entire male pork with various levels of androstenone and skatole by consumers according to their sensitivity to androstenone. Meat Sci., v.90, p.330-337, 2012.

BONNEAU, M.; DENMAT, M.; VAUDELET, J.C. et al. Contributions of fat androstenone and skatole to boar taint: II. Eating quality of cooked hams. Livest. Prod. Sci., v.32, p.81-88, 1992.

BÜNGER, B.; SCHRADER, L.; SCHRADE, H. et al. Agonistic behaviour, skin lesions and activity pattern of entire male, female and castrated male finishing pigs. Appl. Anim. Behav. Sci., v.171, p.64-68, 2015.

CAVALIERI, J.; WANG, M.; JOHNSON, L. Chemical sterilisation of Bos indicus bull calves following intratesticular injection of zinc acetate: effects on semen quality and testicular changes. Anim. Reprod. Sci., v.15, p.23-33, 2015.

CORREA, J.A.; MÉTHOT, S; FAUCITANO, L. A modified meat juice container (ez-driploss) procedure for a more reliable assessment of drip loss and related quality changes in pork meat. $J$. Musc. Foods, v.18, p.67-77, 2007.

DALMAU, A.; TEMPLE, D.; RODRIGUEZ, P. et al. Application of the Welfare Quality ${ }^{\circledR}$ protocol at pig slaughterhouses. Anim. Welfare, v.18, p.497-505, 2009.

DEHNHARD, M.; CLAUS, R.; M.H.; HERZOG, A. High-performance liquid chromatographic method for the determination of 3-methylindole (skatole) and indole in adipose tissue of pigs. $J$. Chromatogr., v.616, p.205-209, 1993.

DUNSHEA, F.R.; COLANTONI, C.; HOWARD, K. et al. Vaccination of boars with a $\mathrm{GnRH}$ vaccine (Improvac) eliminates boar taint and increases growth performance. J. Anim. Sci., v.79, p.2524-2535, 2001.

DUNSHEA, F.R.; KING, R.H.; CAMPBELL, R.G. et al. Interrelationships between sex and ractopamine on protein and lipid deposition in rapidly growing pigs. J. Anim. Sci., v.71, p.29192930, 1993. 
DUTRA JR., W.M.; FERREIRA, A.S.; TAROUCO, J.U. et al. Estimativas de rendimentos de cortes comerciais e de tecidos de suínos em diferentes pesos de abate pela técnica de ultra-sonografia em tempo real. Rev. Bras. Zootec., v.30, p.1243-1250, 2001.

HANSEN-MOLLER, J. Rapid high-performance liquid chromatographic method for simultaneous determination of androstenone, skatole and indole in back fat from pigs. J. chromatogr., v.661, p.219-230, 1994

HOUFMANN, K.; HAMM, R.; BLUCHEL, E. Neus über die bestimung der wasserbindung im fleisch. Fleischwirtschaft, v.62, p.87-92, 1982.

IOCCA, A.F.S.; LUCAS, D.S.; FAUSTO, D.A. et al. Imunocastração e ractopamina na qualidade de lombos suínos processados com sal e tripolifosfato. Pesqui. Agropecu. Bras., v.50, p.417-425, 2015.

IVERSEN, P.P.; HENCKELB, P.; LARSENC, L.M. et al. Tenderisation of pork as affected by degree of cold-induced shortening. Meat Sci., v.40, p.171-181, 1995.

LATORRE, M.A.; POMAR, C.; FAUCINTANO, L. et al. The relationship within and between production performance and meat quality characteristics in pigs from three different genetic lines. Livest. Sci., v.115, p.258-267, 2008 .

LECLERCQ, C.; PRUNIER, A.; MERLOT, E. Effects of neonatal surgical castration and immunocastration in male pigs on blood $\mathrm{T}$ lymphocytes and health markers. Animal, v.8, p.836-843, 2014.

MARTINEZ-MACIPE，M.; RODRÍGUEZ，P.; IZQUIERDO, M. et al. Comparison of meat quality parameters in surgical castrated versus vaccinated against gonadotrophin-releasing factor male and female Iberian pigs reared in free-ranging conditions. Meat Sci. v.111, p.116$121,2016$.
MARTINS, P.C.; ALBUQUERQUE, M.D.; MACHADO, I.P. et al. Implicações da imunocastração na nutrição de suínos e nas características de carcaça. Arch. Zootec., v.62, p.105-118, 2013.

MEAT evaluation handbook. Savoy: AMSA, 2001. p.83-116.

OFFICIAL methods of analysis. $18 \mathrm{ed}$ Gaithersbur: AOAC, 2005. 1018p.

PAULY, C.; SPRING, P.; O'DOHERTY, V. et al. Performances, meat quality and boar taint of castrates and entire male pigs fed a standard and a raw potato starch-enriched diet. Animal, v.2, p.1707-1715, 2008 .

STATISTICAL analysis system. Version 9.2. Cary: SAS,2009.

TUYTTENS, F.A.; VANHONACKER, F.; VERHILLE, B. et al. Pig producer attitude towards surgical castration of piglets without anaesthesia versus alternative strategies. Res. Vet. Sci., v.92, p.524-530, 2012.

VANNUCCHI, C.I.; ANGRIMANI, D.S.R.; EYHERABIDE, A.R. et al. Effects of intratesticular administration of zinc gluconate and dimethyl sulfoxide on clinical, endocrinological, and reproductive parameters in dogs. Theriogenology, v.84, p.1103-1110, 2015.

WALSTRA, P.; MERKUS, G.S.M. Procedure for assessment of the lean meat percentage as a consequence of the EU reference dissection method in pig carcass classification. Lelystad: DLO Institute for Animal Science and Health, 1996. (Report ID-DLO 96.014,).

WEATHERUP, R.N.; BEATTIE, V.E.; MOSS, B.W. et al. The effect of increasing slaughter weight on the production performance and meat quality of finishing pigs. Anim. Sci., v.67, p.591600, 1998.

ZAR, J.H. Biostatistical analysis. 4.ed. New Jersey: Prentice-Hall, 1999. 663p. 